\title{
Michael Gordin*
}

Princeton University

Rosengarten Professor of Modern and Contemporary History

mgordin@princeton.edu

\section{Jan Surman}

Postdoctoral Research Associate Leibniz Graduate School

"History, Knowledge, Media in East Central Europe",

Herder Institute for Historical Research on East Central Europe

(Marburg, Germany)

jan.surman@herder-institut.de

\section{Beyond the center: \\ Sciences in Central and Eastern Europe and their histories}

\author{
An interview with Professor Michael Gordin \\ conducted by Jan Surman
}

\begin{abstract}
What is special about sciences in Central and Eastern Europe? What are the obstacles for writing histories of science done beyond metropoles? Is this science different than the science in the centers and what makes it so? How imperial are sciences made by representatives of dominant nations compared to nondominant nations? These are some of the questions touched
\end{abstract}

\begin{tabular}{|c|c|c|c|c|c|}
\hline \multicolumn{2}{|c|}{$\begin{array}{l}\text { PUBLICATION } \\
\text { INFO }\end{array}$} & Pistoriae & $\begin{array}{r}\text { e-ISSN 2543-702X } \\
\text { ISSN 2451-3202 }\end{array}$ & 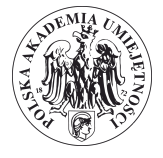 & $\begin{array}{c}\text { } \\
\text { DIAMOND MODEL } \\
\text { OPEN ACCESS }\end{array}$ \\
\hline \multicolumn{6}{|c|}{$\begin{array}{l}\text { CITATION } \\
\text { GORDIN Michael, SURMAN Jan 2016: Beyond the center: Sciences in Central and Eastern Europe and } \\
\text { their histories. An interview with Professor Michael Gordin conducted by Jan Surman. Studia Historiae } \\
\text { Scientiarum 15, pp. 433-452. } \\
\text { DOI: } 10.4467 / 23921749 \text { SHS.16.021.6164 Available online: http://pau.krakow.pl/SHS/shs-15-2016-21.pdf }\end{array}$} \\
\hline \multicolumn{3}{|c|}{$\begin{array}{l}\text { RECEIVED: } \mathbf{2 1 . 1 2 . 2 0 1 5} \\
\text { ACCEPTED: } \mathbf{1 2 . 1 0 . 2 0 1 6} \\
\text { PUBLISHED ONLINE: } \mathbf{2 4 . 1 1 . 2 0 1 6}\end{array}$} & $\begin{array}{c}\text { ARCHIVE } \\
\text { POLICY } \\
\text { Green SHERPA/ } \\
\text { RoMEO Colour }\end{array}$ & 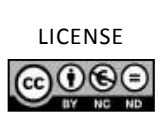 & Crossref \\
\hline WWW & \multicolumn{5}{|c|}{ http://pau.krakow.pl/Studia-Historiae-Scientiarum/ http://ejournals.eu/Studia-Historiae-Scientiarum } \\
\hline
\end{tabular}


upon in the interview with Michael Gordin, a leading historian of science from Princeton University.

Keywords: Central and Eastern Europe - Habsburg Empire • history of science $\bullet$ science and imperialism $\bullet$ science and nationalism $\bullet$ multiculturalism.

\section{Poza centrum: nauki w Europie Środkowo-Wschodniej i ich historie Rozmowę z Profesorem Michaelem Gordinem przeprowadził Jan Surman}

\section{Streszczenie}

Co wyróżnia nauki w Europie Środkowo-Wschodniej? Z jakimi problemami konfrontują się historycy nauki piszący o tym regionie? Czy nauka ta różni się od nauki uprawianej w centrach i w jakim zakresie? Jak bardzo imperialna jest nauka reprezentantów nacji dominujących i niedominujących? To tylko niektóre tematy poruszone w rozmowie z Michaelem Gordinem z Princeton University, jednym z wiodących historyków nauki.

Słowa kluczowe: Europa Środkowo-Wschodnia • historia nanki • nauka $i$ imperializm • nauka $i$ nacjonalizm • wielokulturowość

* A specialist in history of sciences with special emphasis on history of sciences in Russian Empire and the Soviet Union. His early publications concerned Mendeleev and the conditions of science-making beyond the centers (e.g. Gordin 2004; 2008; 2009) as well as the history of the atomic bomb (Gordin 2007; 2010). His next works dealt with the history of pseudoscience on the examples of Immanuel Velikovsky and Trofim Lysenko (Gordin 2012a; 2012b) and, as co-author, the history of the category of rationality during the Cold War (Erickson et al. 2013). In his last book he studied the history of the languages of science before the dominance of English (Gordin 2015). His current project looks at the history of Prague as a scientific city at the crossroads of cultures. 
JS: I would like to start by asking about what moved you to your new project. You started by doing Russian and Soviet history of science and now your new project is about Prague. What moved you to turn to Prague? What is particularly appealing to you as a bistorian of science there?

MG: I started working on Imperial Russia and I tremendously enjoyed the Russian intellectual trajectory, the sources, the language. I found aspects of the research interesting, but I wanted to pursue other options. I was frustrated by the way Russian history of science is separated from the other histories of science. So I looked for ways to connect Russian history of science to German history of science, to French history of science etc. One of the figures who I dealt with in the Mendeleev story ${ }^{1}$ was Bohuslav Brauner, ${ }^{2}$ a Czech chemist who was the first inorganic chemist at the Czech University after the universities split in 1882. He approached Mendeleev and they had an extensive correspondence; Mendeleev serves as a kind of mentor to him. Because of earlier reading I was interested in Czech literature and I thought: why not learn some Czech and see what I can dig out here. I never ended up pursuing this project because Brauner is actually very well studied, but I did learn the Czech material. Then I worked on Cold War topics. And as I started moving back to earlier times, the Czech case became particularly appealing because it provided almost a laboratory. You have two philosophy faculties side by side from 1882 to 1939/45 that are doing similar kind of research with very little contact between them. I thought this would be a good way of exploring national styles of doing science. This is not how I want to proceed now, but it got me interested in the very complex environment of Central Europe, with certain dominant discourses provided by the Russians and the Soviets, earlier by the Germans and the Austrians, and then various competing national discourses - the Czechs, the Poles etc. - all challenging those dominant discourses. That is what makes it a very lively period and region. I later realized that what also made the artistic literature so

${ }^{1}$ Gordin 2004.

${ }^{2}$ Bohuslav Brauner (1855-1935), a Czech chemist, specialized in inorganic chemistry. He studied in Heidelberg and Manchester, worked and subsequently taught at Charles University in Prague, from 1897 as professor. 
good was the mixture of cultures and their mutual engagement, and I wanted to bring parts of that perspective into the history of science. So that is why I shifted to Prague. It was a project I started around the year 2000 and it took a long time for me to get back to it.

JS: What you say about the issue of the dominant discourse and the national discourses sheds a bit of a different light on the question of multiculturalism. There is a heated debate on this issue among the historians of science in Central Europe, with some just concentrating on the entanglements and on the people just being there, sharing one space.

MG: In Prague we certainly see a kind of separation between the Czechs and Germans; at least, the Germans believed they were separated. The Czechs in the late nineteenth century could function in an ordinary society without actually interacting extensively with Germans, unless they wanted to deal with high banking, high industry or the elite levels of academia. Whereas the Germans had to live in a world surrounded by Czechs, especially around 1910, when they comprised around 7\% of the population in Prague. So they were not actually separate, although their discourse presented them as if they indeed were separate and not interacting.

The thing that interests me about the dominant discourse is to figure out precisely how much interaction there really was. One of the differences about how I look at this question as a historian of science in contrast to my colleagues who are general historians is that many of them think that history of science is a specialized subject that has little connection to their topics. Their dominant issues are national discourse, state formation, social movements. The history of science presents a special perspective on these phenomena, because the community of scientists is relatively small, and it tended to be at least partially transnational, partially multilingual. So it possesses many of the features "normal historians" deal with looking at the larger scale, but in some respects is more tractable. What historians of science do is social and cultural history, but of a sort that is sometimes harder to look at from the bigger picture. With German science in Prague you actually have a microcosm of bigger phenomena. 
JS: One of the particularly interesting questions when you look at Prague is the spatial question. There are a lot of informal places where $C_{z}$ ech scholars and German scholars meet, like, famously, the Coffee Louvre.

MG: There are a lot of famous cases of interactions, but also cases where they failed to meet. The chemists from the German University met their Czech counterparts, for example, only in St. Louis in 1904 at the World's Fair. I think that it was certainly possible for Czech scholars and German scholars to never meet their counterparts. But most of them did. If we look at the German-speaking citizens of Prague, those who came from Prague, they typically spoke or understood at least some Czech, however minimally. The Czech scholars always spoke German - at least, this seems to be the case with all the Czech scientists I have ever examined from this late-Habsburg period. So there is the possibility of engagement and it very often happened, yet they do not often speak about it. You can find traces and hints through the geography, correspondence, and diary entries. But when Albert Einstein - the focus of my current Prague project — was in Prague (1911-1912) he interacted with basically no Czech scholars. He met Czechs for example when they were serving people in a restaurant, but he apparently never received invitations to meet the people who were teaching at the Czech University.

JS: As I remember, he had also some Czech students.

MG: He surely had Czech students, but he did not interact with the faculty at the Czech University in the way you might expect. But he also did not interact with the German philosophers at the German University either. It maybe says more about Einstein's patterns of sociability then it says about the city.

$J S:$ Well, there is this ongoing conflict between the representatives of humanities and of natural sciences within the Habsburg Monarchy which dates back to the middle of the century. The first thing the Czechs did in 1918 was to divide the faculty into a natural sciences faculty separate from the philosophical faculty. 
MG: This worked for the philosophers but also worked against them. When Rudolf Carnap ${ }^{3}$ was hired in 1931, he was hired at the natural sciences faculty and not the philosophy faculty. This resembles an arrangement which Einstein had also set up in Berlin earlier for Hans Reichenbach. ${ }^{4}$ The idea was that it is time for natural sciences to work on their own philosophy, separate from the philosophy of the Brentano School and other kinds of philosophy the physicists did not care for. ${ }^{5}$ So philosophers sometimes gain through this separation. Ernst Mach's chair was entirely in Physics when he was in Prague, when he moved to Vienna it included the history and philosophy of physics as well. For the almost thirty years he was in Prague he did a lot of important work in experimental physics, and there is of course also his work in philosophy.

Mach was bilingual. I thought at first that he would not be but there is a good deal of evidence that he was. I found several indications that he would chat with his students in Czech, even if his lectures were entirely in German. He was born in Moravia and lived there through his childhood and he certainly knew enough Czech for small-talk. I had not expected to find that. Because if you read Max Brod's novels and criticism ${ }^{6}$ you would not find out that he knew Czech, because it is all in German, and only rarely do Czech words appear. But it is clear from his interaction with people that he knew the language and could speak it fluently. When he has meetings with individuals like Masaryk, however, the conversation seems to have always been in German.

Part of the reason I turned to Prague now is because I wanted to follow on my language book. ${ }^{7}$ That book is about the "major languages,"

${ }^{3}$ Rudolf Carnap (1891-1970), a German and Austrian philosopher, representative of logical positivism. Studied in Jena and Freiburg and subsequently habilitated in Vienna in 1926 and from 1931 was professor of natural philosophy at the German University in Prague; emigrated to the United States in 1936.

${ }^{4}$ Hans Reichenbach (1891-1953), a German philosopher, physicist and logician. Thanks to Einstein's support habilitated at the Technische Hochschule in Stuttgart (1920) and then received professorship in physics in Berlin (1926). After 1933 he lived in Turkey and then in the United States.

${ }^{5}$ See Hempel 1991.

${ }^{6}$ Max Brod (1884-1968) - a German-language writer, living in Prague and after 1939 in Israel. Known predominantly as a friend of Franz Kafka and the editor of his works.

${ }^{7}$ Gordin 2015. 
the dominant ones like Russian, English, German, and French. The languages which are "smaller" I ignored in the study, because there was no place for them in the dynamics I was focusing on in the text. But I now wanted to see how it looked like in one place with the situation of science in this kind of so-called "minor language". Czech nationalism is so intimately tied to the language. I became interested in the Czech language because I wanted to make the case of Russian science less separate, but I got interested in it once again for its own sake.

JS: So you would agree with Vladimir Macura, who was writing about the linguocentrism of the Czech enlightenment? ${ }^{8}$

MG: I agree. It is also because there are not many options they have to articulate their distinction, the differences that make them a nation. They could not use religion because it was a very sensitive topic in the Habsburg Monarchy, and especially in the history of Bohemia (e.g. the Hussite wars) - and most Czechs were Catholic, not Protestant. You could not use geography because within borders of what counted as the Czech lands you had Germans living there for centuries. When Bolzano9 spoke about his patriotism and calls it Bohemismus, he explicitly includes both Germans and Czechs. But that does not works for the Czechs - in their language there is no distinction as in German, where you have Tschechisch and Böhmisch. In Czech you have only česky. For Bolzano what counts is, to phrase it in the terms of Joseph Matthias von Thun: "weder tschechisch noch deutsch, sondern böhmisch" („neither Czech nor German, but Bohemian”) ${ }^{10}$. You literally cannot translate this idea into Czech. So the Czechs were very constrained: they cannot use religion, they cannot use geography, they cannot use history because the boundary lines have been moved around so many times, so language becomes the one thing they can agree to focus on.

${ }^{8}$ Macura 1995.

${ }^{9}$ Bernard Bolzano (1781-1848) - a Prague Catholic priest, philosopher and mathematician. He was also a public intellectual, entering manifold conflicts with the Habsburg government because of the liberal philosophy he preached. His sermons on regional patriotism are often quoted as the most interesting approach to CzechGerman tensions of his time.

${ }^{10}$ Thun 1845, p. 17; quoted after Agnew 2004, p. 110. 
JS: Czechs and Hungarians are actually the most "Habsburg" cultures. GermanAustrian and Poles in Galicia transgress the boundaries.

MG: And in some ways the state of Czechoslovakia becomes a kind of mini-Habsburg Empire when it is was created. It was not a strictly national state. You did not only have Germans in addition to the Czechs, but also Jews, Hungarians, Ruthenians. So it is a kind of microcosm of what existed earlier, except for the fact that there are no South-Slavs. The Czech Republic today is indeed a nation state, but it took a long time for the country to reach that form.

JS: And the Soviets...

MG: Both Soviets and the Nazis were heavily responsible. You need many changes to achieve that goal.

JS: The reason I asked you about Czechs being the Habsburg culture is the current discussion about Habsburg scholarly culture. There is Ernest Gellner with Wittgenstein and Malinowski, ${ }^{11}$ or Johannes Feichtinger, ${ }^{12}$ who writes about the special political orientation of Habsburg scholars, who want to be political but in a very intellectual way. Since you worked on both Empires, do you see here a different imperial mindset?

MG: I find this a complicated question to answer, because it relies on very contextual definitions of what counts as "political" and what as "intellectual," and those are strongly culture-specific. That is, there are so many variables that one would need to examine: different university cultures (where the Habsburg is not only larger but also older than the Russian), different sensibilities about public discussions in the press, different levels of censorship (although in both cases the censorship was prominent), and so on. I anticipate that if one pushed through and tried to articulate a generalizable "mindset" for Russian scholars, you would find that they shared strong affinities with the Habsburg case, but also bore marked differences. The question would be then how

${ }^{11}$ Gellner 1998.

${ }^{12}$ Feichtinger 2010. 
this compared with other, non-Imperial contexts (the Swedes or the Italians, for example), as well as with Western empires. This is a significant topic to tackle, but also a highly challenging one. The obvious way to start - which is necessary but also always going to be partial and incomplete - is with metropoles (Vienna, St. Petersburg, Moscow, for example).

JS: This is interesting in the way of creating different historiographies of science. If you look at the Russian Empire it is a very Moscow-and St. Petersburg-centric bistory.

MG: Most historiographies of science of the modern period are very university-centric. And Moscow and St. Petersburg are therefore the places people look at, since they have the most significant universities. If you look at the Soviet history, you can find also for example Novosibirsk, which became a major center. But still, most historiography you will find centers on these two locations. This is one of the reasons historians of science working within the Russian frame often leave other Slavic scholars out of the story, because those scholars move beyond these Moscow-St. Petersburg dynamics. The reason it is hard to move beyond this narrative is that the Academy of Sciences and the metropolitan universities control so much, and are indeed so objectively important. I think of this strong focus on the metropoles rather as a virtue not a vice, because it illustrates how elitist the science is and how difficult it is to incorporate a larger diversity of other stories. You have expeditions coming from Moscow and coming back, fostering the knowledge of the provinces. But it is hard to find sources.

\section{JS: You still have cases like the Imperial University in Warsaw.}

MG: Yes, you certainly have them. Warsaw is particularly interesting. But if I would say "I am going to do history of Russian science in Warsaw" that would be a difficult statement to justify. Because it would be a history of Russian and Polish science in Warsaw, so it is already a more complex case. Relatively few Russian universities outside of Moscow and Petersburg get studied: Kharkiv and Warsaw are two of the big ones. But there is also Helsinki, which in the 19th century 
you could subsume under "Russian history of science" - and this gives a good sense of how complicated the question can become.

JS: So it is actually not that different in this point from the Habsburg history of science, where you do Vienna or Gra\%: In my work I try to intervene in favor of the provinces, but it is hard to gain ground. ${ }^{13}$

MG: It is impossible to ignore Vienna, because Vienna is such a powerful place. But my impression of German historiography - especially of general Habsburg historiography - is that today you cannot be a Habsburg historian and ignore the rest of the Empire, focusing on Vienna exclusively. You have to include either the Czechs, or the Hungarians, or the South-Slavs. You have to do some aspect of the trans-regional interactions, because the history is missing something if it only stays in Vienna and Graz and the story remains germanocentric. It loses the specifically Habsburg kind of particularity. So then you also see why Austrians made the decisions they made, which are invisible unless you know what the Hungarians, Czechs or Poles are doing.

JS: What is your opinion about the thesis of particularity of the empires and their knowledge?

MG: The empires that are studied from this angle are mostly British, French and partly Spanish empires and I do not know the literature that well to draw general conclusions. There are obviously similarities between the Habsburg and Russian cases, but I cannot say whether those similarities stem from the fact that they are empires, that they are landlocked empires, whether it is simply mutual learning, or some other reason. They are, after all, right next to each other and they look at each other. Thus to explore the imperial mindset you mention requires much more work and is an open research question. It also requires that you find the characteristics of, for example, British science in India that are at the same time similar and different from the Russian and Habsburg cases. To figure out whether those similarities or differences are functions of the scientific questions people are asking, whether they are

\footnotetext{
${ }^{13}$ Surman 2012.
} 
functions of the imperial or state structures, of the time period, or whether they are - and we know this is true - a result of the fact that they all look at each other. Russians look at the British, the British are looking at the Austrians and Austrians are looking at the Germans. Everybody is copying techniques from the others.

One particularity of the history of science as opposed to general history is that it always involves communication across these boundaries. The French scholars are never addressing only the French scholars, they are addressing also the English or the Germans; they have conferences together and they travel to each other's places and they see what is going on. So at the very least what was happening was transnational. If it is "global" is another, more complicated question, because some parts of the globe - like Latin America - have largely been excluded from these exchanges. Part of the reason we know so little about Latin American science in the $19^{\text {th }}$ century is that not much scholarship has been produced about them, at least as compared with the overwhelming density of literature on German science, British science in the colonies, and English science in the metropoles. About the rest of Europe and the Empires, we just know much less. For the scale of Russian and Soviet science, we have much less historiography than you would expect there to be.

JS: And I would even add that these central historiographies would really profit from looking at what is happening in different parts of their states and empires. For instance in the ways of bierarchies: while both German and French are quite monolingual sciences, or are in the process of getting monolingual in the nineteenth century, when the Germans were getting out of the complex about the French and the French developed complexes about the Germans.

MG: If you look at the time of Napoleon, this makes much more sense and you see how strong this complex is. The British had a French complex too, and you can find a great deal of it by doing a comparison between these two. The missing part of the puzzle is always knowing the other historiography. This has been an improvement in the historiography of science lately. Historians of science looking at a particular science are required to know about the other historiographies as well. They are limited linguistically - if you are for instance a historian of 
the French Empire you might not read German and then you can read only what is available in English and French. So the more translations there are, the more multiple publications there are, the better the picture of interchange and interactions.

But it is harder to get people working on the history of science in the empires. When I think about the core historiography of science at present, the emphasis now is on post-war and recent science. This is in part because more science was done in that period than earlier, thus there is more to cover. And considering the scale of the phenomena, it is relatively underexplored. The early nineteenth century seems to me understudied at present.

JS. I have the feeling that in Central Europe and its historiography it is the opposite. $1^{\text {th }}$ century is overstudied and Cold War science is seriously understudied.

MG: You are right. My first hypothesis about why Central European science during the Cold War was understudied was because of linguistic limitations. Scholars who are interested in the $19^{\text {th }}$-century Central European history have to know German, but they often do not know Russian, which is necessary if you want to explore the $20^{\text {th }}$ century history. And scholars who know Russian do not always know Hungarian or Czech. If they are interested in Soviet Science, therefore, they concentrate on the Cold War and Russian-American connections. So we have problems with our training practices, people with different sets of skills are working on different topics.

JS: Before coming to the part on the Cold War, I wanted to go back in time a bit into the intervar period. You probably know the thesis about epistemic inbetweenness by Matgorzata Mazurek. ${ }^{14}$ I do not completely agree with her, because you find the argument of epistemic inbetweenneess everywhere, if you look. for it. Even in France at certain points of time, when they were for instance regarding themselves as being between the American and the Germans. Do you see things like this also in your case studies?

MG: I would say yes, but I also think the reason you are not persuaded by it is right, because national categories are the wrong way of looking

${ }^{14}$ Lebow et al. 2015. 
at it. It is not that Polish science is in-between Russian and German science. It is also that individual members of Russian or German scientific community are epistemically in-between. The Polish community is also not homogenous: you have some scholars who are not in-between German and Russian science but are purely German. That is, they are trained in Germany, they studied German science and that is what they do. But there are people who oscillate, who have mixed training, and that produces interesting effects. The national boundary is just not the right way of finding these people. Usually it is by biography, locating people who worked with multiple contacts. Brauner is someone who oscillated between British contacts (he studied in Manchester) and Russian ones, which he cultivated. That is to some extent political, figuring out a language and community he can connect to. This is important for Prague if you are the son of an important nationalist and you are trying to build a Czech university. But it also has some interesting epistemic consequences.

JS: When I was working on the idea of imperial biography in the $19^{\text {th }}$ century, I analysed Josef Dietl, who is Galician but studies in Vienna and when he comes back to Galicia he is getting very national but it is a peculiar kind of nationalism, very conciliatory. And then I compared him with Masaryk, who is also trained in the very center, and who is a nationalist but also a "bumanist" and not a nationalist in the Czech sense. And I connected it with the experience of otherness in Vienna. ${ }^{15}$

MG: You are right. But you can make this argument for, say, people like Einstein, who is born in Ulm but then he switches his identity to Swiss. Then he worked in a multinational empire, stayed Swiss, and then became German again.

This process of imperial exchange when people go and then they study in multiple places and then come back seems to me very important in how the Habsburg and then Habsburg-German relations emerge. Even after the Austro-Prussian war, the University of Vienna is still part of German university system, as is Zürich. People move among these universities. So there is a way in which scientists are transimperial,

\footnotetext{
${ }^{15}$ Surman 2015.
} 
they are going from Graz to Černivci (Chernivtsi, Czernowitz), to Kraków (Cracow), and maybe to Vienna if they are lucky. And that is the process, that is the empire again. And this process is a very interesting feature of German-language academia.

JS: Well, there is this a linguistic differentiation taking place in the 19th century, so from Vienna you would not easily go to Cracow when Cracow is becoming a Polishlanguage university. Or you really know the language, and there are only a handful of people who do.

MG: This is also part of the reason Masaryk keeps the German University open. Because it brings people into Prague. It makes the city less provincial. Germans and Austrians come to Prague and teach. Or even Russians. You do have cases like Roman Jakobson, who moved to Prague from the Soviet Union and taught in Czech at the Czech University. But that is exceptional and there are only few people like that. Most people teaching are Czechs.

JS: There is also a Russian University in Prague, and a Ukrainian university in Prague who also draw people from abroad.

MG: Yes, but there is less exchange with Czechs happening there. And Jakobson is teaching at Charles University.

JS: With this idea of Vienna at the center, I was thinking about Bruno Latour's concept of center of calculation. ${ }^{16}$ But it is not restricted to the imperial centers. Cracow University is doing basically the same thing, they are sending people for scholarships for a few years, they are obliged to write and publish reports, and quite long ones. Then they also have to babilitate in Cracow. And everything is paid by the Habsburg government.

MG: This is in fact similar to what was happening in Russia after the Crimean War. Lots of scientists and legal scholars who were smart students were sent to Heidelberg, Zürich, or Vienna to study with someone for two or three years, then come back and then they brought back

\footnotetext{
${ }^{16}$ Latour 1987, pp. 179-257.
} 
with them all the knowledge, the reports on what they did. This was the project I was working on after finishing the Mendeleev biography, centered on the students who spent time in Heidelberg. In the end, I could not find a way to make the story confinable within a single book. ${ }^{17}$

JS: This brings me to another term closely linked with it: provincialization, and selfprovincialization. There was an intense discourse about it in interwar Poland and it also has much to do with shedding imperial power and getting national, and people not being content with getting nationally confined. How does it work with Prague, where it is a city with such a lively scholarly culture?

MG: One of the reasons I am attracted to Prague is because it is both a center and a periphery. And that was true in the Habsburg period too. There were some self-provincializing scholars who published in Czech and did not care if they get cited anywhere else, both in the imperial period and the national period. But even in the Habsburg period Prague was such an important center of industry and commerce, being half-way from Vienna to Berlin. It already had a central position even if it was on the edge of the Empire. And yet it was not Budapest or Vienna, not a metropole. I do not know if Cracow served a similar function, but Chernivtsi clearly did not, neither did Innsbruck. The fact that Prague was both central and peripheral is one of the reasons why it is such an interesting intellectual city. You can choose to be incredibly narrow and focused but you can also choose to be imperiallyminded or transnational or transimperial. And the same person can act differently at different times of their career. There are not that many cities where you can do that. If you live in Paris, it is hard to provincialize yourself, because of the way Paris is set up. And in Marseilles it is impossible to make yourself central. In Prague you can do both.

JS: It seems that is a good switching point to the Cold War. Because when I think about historiography of science of the Cold War, one of the big problems I have is that our categories are completely Western-European. Derrida or Foucault are very French when they write their work - the way how to think about the center, or to deconstruct the center. And we are still using the same categories working on the

\footnotetext{
${ }^{17}$ Gordin 2008.
} 
Michael Gordin, Jan Surman

Beyond the center: Sciences in Central and Eastern Europe and their histories...

pan-European perspective, or even global one. There are people criticizing it Provincializing Europe would be the first step in this direction. ${ }^{18}$ Since you work at a department which has a nice dynamics of europeanists and non-europeanists, how do you perceive this issue?

MG: One of the things that struck me this year in Germany is the prominence of Fleck in the conversations on Europe. That is relatively new. He was, as you know, very little read when he was first published, and then Kuhn's success popularizes Fleck, especially through translation. I think one of the reasons he is so popular now is that he comes from a different tradition and provides tools which are more suited to the questions you are asking now. And the differential reception of Bruno Latour is similar. The places he is popular are centers of some kind. He is popular in Russia, popular in France, but I do not know how he suits the pan-European perspective.

One of the issues I was discussing more intensively recently is that there is a rich apparatus which is developed by Czech historians of science, Polish historians of science in the $19^{\text {th }}$ and early $20^{\text {th }}$ century, like Emmanuel Rádl ${ }^{19}$ for instance. They are not known except for specialists who are writing about this topic; they are certainly not known to the Anglophone community. When I read the early history of science, there is a lot stuff going on which does not get picked up later. The scholarly community does a lot of nice work with Kuhn, Butterfield and Needham at the beginning, but they only picked up certain ideas. And if you get back to these more neglected studies you can pick up different ideas produced by different contexts. I do not know for instance who the Romanian thinkers about science in the early $20^{\text {th }}$ century were, but they certainly existed and some of them might be interesting and useful for us today. It would be nice to have a more engaged conversation about these different epistemologies. It might be that most of them are no longer relevant, highly tied to the state of

${ }^{18}$ Chakrabarty 2000.

${ }^{19}$ Emmanuel Rádl (1872-1942) - a Czech biologist, philosopher, science organizer and important intellectualist of the interwar period. His book Geschichte der biologischen Theorien (1905-1909) played an important role in the historiography of sciences of the early 20 th century and had several editions and translations. 
science at that time. But Fleck is an example of a historian of science who is not. And if you can find more people like Fleck, that would be really fascinating.

\section{$J S$. Another person who is having a triumphal return right now is Lotman.}

MG. And Shklovsky as well. Lotman has a very prominent career, Shklovksky is confined to literary studies, which are very much influenced by Russian formalism. Lotman is everywhere. There was a time of Bakhtin, who was becoming important, but it seems the enthusiasm has somewhat died down. His work was a tool useful for very specific questions, and hard to generalize. Lotman intended to have a system to explain everything and he is being used for that.

Recently I was reading dialectical materialist philosophers, for two reasons. First is the historical interest. They served an important personal function. They were educated in Moscow, but then they come to Prague, or to Brno, linking professional science in the communist states. But they also have occasionally extremely interesting ideas about how science operates. The thinkers that are more interesting are those who were not publishing in Russian, and almost no one reads them, because if you work on dialectical materialism you would assume that everything was in Moscow and was dictated from Moscow. But it was not. If you look at Filosofický časopis, there are a lot of interesting debates with Yugoslav philosophers. There are different questions they are asking because they are removed from the center. Historians always look at the links Prague-Moscow, they do not look at Prague-Warsaw.

JS: It is similar with what has happened in Germany after die Wende. There is a bunch of good historiography of science, which got forgotten and is ignored and is not read anymore.

MG: I am curious if it will stay ignored. Right after World War II a lot of völkisch thought was ostensibly suppressed, for example Carl Schmitt's writings. And then those ideas came back. In some cases it is productive and it some cases it is disturbing. If scholars go back and try to think about some of these writers on their own terms, it may prove rewarding, and the same is true for the Communist writers. If they focus 
on the ideas not as a pathology that infected philosophy of science or history of science, I think we can find there something interesting. Certainly, if you write on history of science in, for example, communist Poland, you cannot do it without reading what the historians of science working at the time thought was happening. Reading their works on the $18^{\text {th }}$-century science will give you a picture on what topics were on the rise in the scientific community.

JS: Directly after the World War II many Polish philosophers were translated into the "western" languages, like French or Italian. And this somehow got lost too.

MG: One of the reasons I think this got lost is the predominance in philosophy of science of Anglo-American philosophy, which is in its origin Viennese but has muted all the alternative traditions in a way. And this is why philosophers working now have not typically been interested in these questions. But historians of science should be, because they may have conceptual tools which are quite useful.

JS: And the Viennese tradition of philosophy of science is also connected and similar to Lviv-Warsaw school, which also gets translated in the US, like Tarski.

MG: There are multiple paths by which you go from Mach and Carnap. Early Wittgenstein, Lviv-Warsaw School, also Russell picking it up and bringing it into English. There are lots of different ways it became dominant.

Die Wende has produced a kind of erasure of some of the traditions that were there and this is why I am now interested in Cold War science as a topic. Many institutions of the Cold War are gone, but the Cold War ideologies are still present, although not in a simplistic way. We have the distance today to travel back and uncover some of the ways people were thinking about the system of science we have now while it was still in the process of being erected. And looking at that time provides a very fruitful way of thinking about the science in our current world. I can defend the thesis that the current science system was born in the Cold War, but this would be a topic of a longer conversation. 


\section{Bibliography}

AGNEW Hugh $L$.

2004: The Czechs and the Lands of the Bohemian Crown. Stanford: Hoover Institution Press.

CHAKRABARTY Dipesh

2000: Provincializing Europe: Postcolonial Thought and Historical Difference. Princeton: Princeton University Press.

ERICKSON Paul, KLEIN Judy, DASTON Lorraine, LEMOV Rebecca, STURM Thomas, GORDIN Michael

2013: How Reason Almost Lost Its Mind: The Strange Career of Cold War Rationality. Chicago: University of Chicago Press.

FEICHTINGER Johannes

2010: Wissenschaft als reflexives Projekt. Von Bolzano über Frend zu Kelsen: Österreichische Wissenschaftsgeschichte 1848-1938. Bielefeld: Transcript.

GELLNER Ernest

1998: Language and Solitude: Wittgenstein, Malinowski and the Habsburg Dilemma. Cambridge: Cambridge University Press.

GORDIN Michael

2004: $\quad$ AWell-Ordered Thing: Dmitrii Mendeleev and the Shadow of the Periodic Table. New York: Basic Books.

2007: Five Days in August: How World War II Became a Nuclear War. Princeton: Princeton University Press.

2008: The Heidelberg Circle: German Inflections on the Professionalization of Russian Chemistry in the 1860s. In Karl Hall, Alexei B. Kojevnikov (eds.), Intelligentsia Science. Special issue of Osiris 23 (2008), pp. 23-49. Available online: http://www.jstor.org/stable/40207002 (retrieved:14.09.2016).

2009a: Points Critical: Russia, Ireland, and Science at the Boundary. Osiris 24, pp. 99-119.

2009b: Red Cloud at Dawn: Truman, Stalin, and the End of the Atomic Monopoly. New York: Farrar, Straus and Giroux, 2009).

2012a: How Lysenkoism Became Pseudoscience: Dobzhansky to Velikovsky. Journal of the History of Biology 45/3, pp. 443-468.

2012b: The Pseudoscience Wars: Immanuel Velikovsky and the Birth of the Modern Fringe. Chicago: University of Chicago Press.

2015: $\quad$ Scientific Babel: How Science Was Done before and after Global English. Chicago: University of Chicago Press. 
Michael Gordin, Jan Surman

Beyond the center: Sciences in Central and Eastern Europe and their histories...

HEMPEL Carl G.

1991: Hans Reichenbach Remembered. Erkenntnis 35 (1/3), pp. 5-10.

LATOUR Bruno

1987: Science in Action: How to Follow Scientists and Engineers through Society. Cambridge, MA: Harvard University Press.

LEBOW Katherine, MAZUREK Małgorzata, WAWRZYNIAK Joanna, BRUNNBAUER Ulf

2015: Epistemologies of In-Betweenness: East Central Europe and the World History of Social Science, 1890-1945. International workshop at the Institut für Ost- und Südeuropaforschung Regensburg, 29.05.201530.05.2015.

MACURA Vladimír

1995: Znamení zrodu: české národni obrození jako kulturní typ. Jinočany: H \& H.

RÁDL Emmanuel

1905-1909: Geschichte der biologischen Theorien. Leipzig: Engelmann.

SURMAN Jan

2012: Habsburg University 1848-1918. Biography of a Space. Nieopublikowana praca doktorska, Uniwersytet Wiedeński. Available online: https://www. academia.edu/16713182/ PhD Thesis Habsburg Universities 1848 - 1918 biography of a space. Wien Univ. Diss. 2012.

2015: Imperiale „go betweeners”: Józef Dietl und Tomáš Garrigue Masaryk. [In:] Tim Buchen, Malte Rolf (Hrsg.): Imperiale Biographien: Elitekarrieren in den Vielvölkerreichen der Romanows, Habsburger und Osmanen (1850-1918). Berlin: De Gruyter, pp. 311-337.

THUN Joseph Matthias von

1845: Der Slawismus in Böhmen. Prag: Calve. 